\title{
THE ENDURING IMPORTANCE OF ENTREPRENEURIAL MOTIVATION FOR GROWTH
}

\author{
Abayomi K. Akinboye \\ University of Canterbury • Christchurch, New Zealand \\ Jamie D. Collins \\ University of Canterbury $\bullet$ Christchurch, New Zealand \\ Sussie C. Morrish \\ University of Canterbury • Christchurch, New Zealand
}

\section{ABSTRACT}

For decades entrepreneurship scholars have advanced the frontier of knowledge in venture growth. More recently the desire to understand the motivation for different phases of business development (e.g., initiation, growth, and exit) has necessitated a review of literature on venture growth and the motive for entrepreneurial actions at these stages. We have conducted a comprehensive and critical review of empirical contributions on venture growth and entrepreneurial motivation. Interestingly, we identified a lack of unity in the meaning and measures of growth as the reason for the fragmentation in theory development. We highlight that the motives for engaging in entrepreneurial actions may differ based on the stage of entrepreneurial development. We also highlight the importance of keeping entrepreneurial motivations as a major focus area for scholars in this domain particularly as an enabler of growth intention.

\section{INTRODUCTION}

Entrepreneurship is a foundational component required for economic and societal achievement. The creative prowess entrepreneurs bring to the task of solving the needs of others in society can spark a virtuous cycle of improved market efficiencies, economic growth, enhanced standards of living, and higher levels of health, as well as providing accompanying improved educational and societal outcomes. Given these benefits from entrepreneurial activity, it is therefore in the interest of all economies that enterprise grows. The numerous potential benefits of entrepreneurship and increasing motivation for societal impact have contributed to the flourishing of entrepreneurship research over the past several decades. 


\section{ENTREPRENEURIAL GROWTH INTENTION}

Entrepreneurial intention beyond start-up is gaining momentum in entrepreneurship research, and growth intention is increasingly a focus of interest. While there are many drivers of entrepreneurial growth, scholars seem to be nearly unanimous in the view that growth intention precedes actual growth (Knockaert et al., 2015; Puente et al., 2017; Rasmussen et al., 2016). Entrepreneurs' growth intention has been found to evolve as entrepreneurs interact with the environment, which presents opportunities and constraints. Intention to growing ventures in such an environment is motivated by perceived opportunities, achievement needs and perceived ability to navigate such environment (Davidsson, 1989, 1991).

The motivation for start-up usually determines the venture types, and that commonly influence the growth intention of entrepreneurial firms (Edelman et al., 2010; Jayawarna et al., 2013; Morris et al., 2016). Internationalising entrepreneurial firms with their export propensity are also found to have growth intention (Moen et al., 2016). For example, Spence et al. (2011) noted that owners of firms that internationalise early expressed their intention to pursue growth, and this was notably lacking in their counterparts owning domestic new ventures.

Equally seen as important is entrepreneurial passion. Some scholars believe that motivation has more to do with start-up while passion has been attributed to strength to continue the entrepreneurial process despite challenges along the way; therefore entrepreneurial passion and persistence are strongly linked (Cardon \& Kirk, 2015). Entrepreneurial passion has been anchored on the entrepreneur's self-identity (Baker et al., 2017; Morris et al., 2016) with the role salient to the self-identity of the entrepreneur such as inventing, founding and developing used to describe the passion of entrepreneurs (Cardon et al., 2013). Generally speaking, these identities are linked to intention (Biraglia \& Kadile, 2017; Dalborg \& Wincent, 2015) while identity such as passion for developing is positively related to growthoriented entrepreneurs (Cardon et al., 2013; Mueller et al., 2017).

The importance of cognition in the evolution of growth intention has also attracted much attention from scholars. Entrepreneurial cognition observes the complex interaction between the entrepreneur and the environment (Armstrong et al., 2012; Baldacchino et al., 2015). In a very recent study, Akinboye, Morrish and Collins (2019) found the dominance of emotion over cognition in the formation of growth decisions and acknowledges the hostile and limiting role of the context in which they operate, hence dwindling motivation to pursue entrepreneurial opportunities that could lead to growth. Entrepreneurs' decision and intention for 
growth-oriented ventures have been linked to their cognitive styles and logics (Dutta \& Thornhill, 2008; Wright \& Stigliani, 2013), thus worthy of further investigation.

\section{Defining Growth}

Entrepreneurship scholars have discussed venture growth for decades with limited progress in pinpointing precise cause-effect relationships. Leitch et al. (2013) argue that for almost 50 years, researchers have shown substantial interest in this entrepreneurial phenomenon. However, the journey has been stagnated by the complexity and confusion surrounding it. The inconsistencies in the way growth have been measured (Weinzimmer et al., 1998) in extant literature alluded to the fact that it has a different meaning to stakeholders. Gibb (2000) noted that the four main stakeholders (policymakers, business owners, academics, and others, e.g., customers, funders, and suppliers) attached a different meaning to this phenomenon. To some, growth means more jobs created while others see growth as the generation of greater revenues. This is also evident in academic research as different scholars use a range of different measures to assess business growth.

Policymakers' interest in employment creation means they favour using "number of employees" as a measure of growth, while business owners with a desire for profitability prefer sales-related indicators. These two measures dominate the entrepreneurship literature. For example, Weinzimmer et al. (1998), analysed 193 firms in 48 industries using comparative regression analysis and found that the significance of relationships between growth and the explanatory variables, as well as the amount of explained variance, is subject to the particular concept of growth utilised. Furthermore, they noted that sales growth (42.8\%) was better explained with a set of commonly used explanatory variables from literature than were either employee growth $(29.2 \%)$ or asset growth $(28.3 \%)$ using various formulas. Interestingly, this view was supported by others accepting that "for most purposes, sales is the more relevant growth indicator" (Davidsson et al., 2009, p.395). Some scholars advocated for an inclusive measure (Delmar et al., 2003; Havnes \& Senneseth, 2001; O’Gorman, 2001), stressing that using integrated measures will provide a comprehensive examination of any empirical relationships and allow testing for the robustness of any theoretical model (Dobbs \& Hamilton, 2007). However, McKelvie \& Wiklund (2010) maintain that the advancement of knowledge stalled in venture growth research due to the focus on "how much" rather than on the "how". 


\section{Mode of Growth}

For the advancement of knowledge in venture growth research, there needs to be a shift in focus from growth rate to growth mode. Scholars have suggested that more attention should be given to "how" growth occurs before answering the "how much" question (McKelvie \& Wiklund, 2010; Wright \& Stigliani, 2013). In a review of 82 empirical studies from 11 top management journals ranging from 1992 to 2006 (Shepherd \& Wiklund, 2009), several attempts were made by scholars to explain differences in growth but totally ignoring the process or path of growth. As a result, the literature on venture growth has been highly fragmented making it difficult to compare studies (Shepherd \& Wiklund, 2009) which according to Davidsson $\&$ Wiklund (2008) has hindered theoretical advancement. In order to unravel the complexity surrounding firm growth as an entrepreneurship phenomenon as well as "keep up with changes in how contemporary firms choose to grow", it is expedient that there is practical clarification of growth mode (Nason \& Wiklund, 2018, p. 54). In the same vein, Gilbert et al. (2006) in their extensive review of literature on new venture growth note that without a proper understanding of growth mode, it will be difficult to explain growth outcomes and how their underlying mechanisms (either internal or external) produce different impact. McKelvie and Wiklund (2010) support this view and arguing that prioritising research on modes of growth is imperative for a better understanding of the causal mechanisms that explain growth. Entrepreneurship scholars have classified the process by which growth can occur into three modes: organic, acquisitive, or hybrid ( Koryak et al., 2015; Lockett et al., 2011).

Organic growth (also referred to as internal growth mode) relied on product development and internal research and development (Chen, Zou, \& Wang, 2009) and firms that focus on organic growth invest in $\mathrm{R} \& \mathrm{D}$ for possible new product opportunities in order to enhance their product portfolio (Zahra, 1996). Consequently, firm's innovation ability is enriched, leading to strong technological capability with frequent product upgrades, patents as well as valuable technology sources which spur organic growth (Zahra et al., 2006). Organic growth brings about genuine job creation, but employment growth in an acquisition is usually a form of movement of jobs from one firm to another (Chen et al., 2009).

Growth through acquisitions is a mode whereby a business acquires an existing firm or business in the same or other business areas. This strategy provides the fastest trajectory for strategy implementation and growth such as market expansion, however, firms that follow this path are often faced with the challenge of integration which is absent in organic growth (Agnihotri, 2014). Although growth 
through acquisition does not provide any net increase to the economy but afford firms opportunities to reach and explore new markets without developing (Davidsson et al., 2010; Gilbert et al., 2006). This is worth noting because a study of a dataset comprising a 10-year panel (1987-96) of more than eleven thousand commercially active Swedish enterprises in the private (non-government) sector with 20 or more employees by Lockett et al. (2011) discovered something interesting. They found that firms that have organically grown in the past might find it difficult to experience another organic growth, whereas past acquisitive growth is found to lead firms into future organic growth. Therefore, a combination of growth strategies (hybrid) becomes necessary to overcome "traditional limits to firm growth" resulting from environmental dynamism of business landscape (Dagnino et al., 2017, p. 427).

\section{Entrepreneurial Growth Intention and Actual Growth}

Studies have found evidence that firm personal growth objectives are themselves predictive of subsequent growth (Delmar \& Wiklund, 2008; Wiklund \& Shepherd, 2003). In a longitudinal study of Swedish entrepreneurs, Delmar \& Wiklund (2008) found small business owners' growth motivation have a positive impact on subsequent venture growth regarding employment growth, but in term of sales growth, the evidence is limited. Establishing this kind of relationship requires longitudinal data: collecting data at the intentional stage and after that as well. Another study conducted in Finland (Stenholm, 2011) examined longitudinal data from 232 small and medium-sized businesses. The results show the existence of a positive relationship between growth intention and firm growth, but innovative behaviour weakens this relationship.

Previous studies that confirmed this relationship have also shown that the relationship between growth intention and realised growth is mediated or moderated by other factors such as resources and opportunities (Delmar \& Wiklund, 2008; Wiklund \& Shepherd, 2003). The evidence reviewed here seems to suggest a pertinent role for growth intention as predictor of growth. With the perceived benefits to the economy, venture growth research has enjoyed attention for decades (Mason \& Brown, 2013). Douglas (2013) suggests that entrepreneurial intention should extend beyond start-up intention in order to identify firms with growth tendency. Integrating heterogeneous opportunities and 'individual-opportunity nexus' in the entrepreneurial intentions model, Douglas found that entrepreneurs at the intentional stage show different growth intention, which eventually impacts their choice between independence and growth-oriented new ventures. 


\section{DETERMINANTS OF SMALL BUSINESS GROWTH}

In an attempt to classify growing firms, entrepreneurship scholars have investigated factors seen as determinants of growth. These factors are broadly categorised as external and internal. However, various scholars approach these classifications differently. In particular, some studies focused on the entrepreneurs and the context (environment) (Hitt et al., 2000). Others looked at the entrepreneur, the firm and the strategy of the firm. Moreover, Baum, Locke, \& Smith's (2001) large US study (with a sample of 307 companies in the same industry) found that entrepreneur's motivation have a direct impact on venture growth while the environment has indirect effects. The motivation result from self-efficacy, growth goals and vision with other factors such as general and specific competencies of the chief executive officers as well as competitive strategies. In a later longitudinal study, Baum \& Locke (2004) examined entrepreneur's motivation (comprising goals, selfefficacy, and vision) finding that all three have direct effects on venture growth.

Growth occurs at the intersection of three spheres: entrepreneur, firm and strategy. All these components must connect properly for rapid growth. The entrepreneur makes decisions, and the firm chooses the right strategy for the execution. Non-growing or failing firms are often deficient in at least one area. The ultimate challenge is the appropriate combination of these components. The presence and proper combination of these characteristics can be a predictor of growth, while the absence or neglect of one or more could be a barrier to growth. For instance, the willingness of the entrepreneur to share equity with external entities such as banks and angel investors could accelerate growth while their reluctance could be a barrier or constraint on growth. Interestingly, Wiklund et al. (2003) found that firms that experience little or no growth are primarily due to their unwillingness to grow. Thus, the most strategic decision lies with the entrepreneur (Shepherd et al., 2015; Vermeulen \& Curşeu, 2010) and decisions on "how much to grow" is often made in the early years of the firm which "have profound, long-lasting implications for performance” (Gilbert et al., 2006, p.929).

Understanding the decision-making process of the entrepreneur is imperative. As research in the field of entrepreneurship advances, scholars have turned their attention to cognitive variables to understand the growth-related decision of the entrepreneurs (Armstrong et al., 2012; Baldacchino et al., 2015). According to Wright \& Stigliani (2013), an attentive perusal of entrepreneurs' growth decisions as well as the knowledge structures and cognitive styles used in the process will advance knowledge in the field of entrepreneurship. Indeed, entrepreneurial decision-making 
can not be overemphasised as founders decisions on which activities to delegate or engage in themselves determine a venture's survival and growth (Haeussler, Hennicke, \& Mueller, 2019). In a longitudinal qualitative study of 30 entrepreneurs in Western Canada over a five-year span, Dutta \& Thornhill (2008) found that entrepreneurs' cognitive styles determine their approaches toward framing and reviewing growth intention. Their study further revealed that their cognitive style shapes entrepreneurs' growth intention resulting from their environmental perceptions. Knockaert et al. (2015) also maintain that the formation and promotion of growth intention among academic entrepreneurs are contingent upon cognitive style. Evidence suggests that cognitive style plays a vital role in the formation of growth intention, however, little is known about this in other contexts. For example, some regions offer a unique characteristic from the rest of the developed world. A significant number of the empirical works done on entrepreneurial growth were conducted in Sweden and the United States. However, entrepreneurship scholars have stressed the importance of the context in which the entrepreneur operates. There is substantial evidence that contextual factors like location, industry, market, environmental hostility and institutional environment affect entrepreneurial behaviour (Puente et al., 2017; Wiklund, Patzelt, \& Shepherd, 2009).

\section{BARRIERS TO SMALL BUSINESS GROWTH}

Small and medium enterprises (SMEs) are a catalyst that spurs economic growth. Their growth means more jobs and revenue for the economy, however, their pursuit of growth is not without challenges (Collins \& Reutzel, 2017, Collins, McMullen \& Reutzel, 2016). There is a considerable volume of literature on barriers to SMEs growth involving studies conducted in developed and developing economies as well as transition economies. The findings show that some of these barriers are peculiar to economic status. In a survey of 219 SMEs in Western Canada, Gill \& Biger (2012) found that a number of issues could hinder SMEs growth. Some of the issues identified are market challenges, lack of financing and regulatory issues. This view is supported by Lee (2014), who investigated obstacles to high-growth firms' performance in the United Kingdom using quantitative data from 4,858 SMEs. The results suggest that firms in periods of high growth face challenges such as cash flow, securing finance, shortages of skilled labour and finding suitable premises but are less likely to see regulation as a major challenge. In addition, Romero-Jordán et al. (2019) studied the impact of corporation tax on productivity growth in Spain and found that SMEs growth in the area of productivities is hampered by corporation tax 
more than the bigger firms. In New Zealand, Hansen \& Hamilton (2011) identified "controlled ambition of the owner-manager to grow" as a major obstacle to growth. While documenting the evolution of small business policy in Australia and New Zealand in the last 46 years, Mazzarol \& Clark (2016) claimed that access to financing and credit is a pertinent issue. Exploring investor readiness in Australia, Douglas \& Shepherd (2002) suggest that the venture capital industry in Australia is less mature compared to the US.

In another set of studies carried out in former centrally planned economies that have transited or are transiting to a market economy, researchers found that entrepreneurs in this type of environment face something unique. For example, Hashi (2001) surveyed SMEs in Albania and reported that the primary barriers to SMEs growth are those caused directly or indirectly by the state. The study noted that financial constraints resulting from fiscal policy (mainly high rate of taxes and contributions coupled with the poor institutional environment) hinders entrepreneurs.

Similarly, Krasniqi (2007: 71) studied 178 SMEs in Kosovo and concluded that "legal environment, administrative burden, external financing, tax burden and unfair competition" hinder the growth of SMEs. Additionally, other factors associated with the institutional environment, such as external financial constraints as a result of the high cost of capital and bureaucracy, were also identified (Bartlett \& Bukvič, 2001). Attempting to sort out the most significant obstacles facing SMEs in developing countries, Wang (2016) analysed data from 119 developing nations and noted that access to finance is perceived as the most significant obstacle by owner-managers. Although there are other issues such as political instability, lack of electricity and corruption, barriers to external financing (because of the high costs of borrowing) ranked the highest.

Almost every study conducted in various developing countries on growth supported these findings. For instance, across India, researchers discovered that small business growth is hindered by a variety of challenges which include the shortage of working capital, power shortage, market challenges, regulatory issues and management problems (Coad \& Tamvada, 2012; Gill \& Mand, 2013). Robson $\&$ Obeng (2008) surveyed 500 entrepreneurs from all six regions in Ghana and reported the three greatest problems highlighted by these entrepreneurs comprising of the high rate of inflation, high-interest rate and currency depreciation. Another study from South Africa noted that "difficulty in securing loans, lack of training opportunities, and shortage of entrepreneurial skills" adversely influenced small, micro and medium-sized business enterprises (Worku, 2016, p. 134). Although some of these factors are unique (depending on the circumstances surrounding the 
economies), collectively, evidence reviewed here outline a critical role of finance in entrepreneurial growth as financial issues resonated across all economic status. Similarly, Beck \& Demirguc-Kunt (2006: 2942) in their review of literature on access to funding by small and medium-size enterprises concluded: "that access to finance is an important growth constraint for SMEs".

Acknowledging the role of resource constraints in the entrepreneurial process, scholars in the field of entrepreneurship have paid close attention to effectuation logic for over a decade which emphasises available resources as a "source of entrepreneurial opportunity" and "resource constraints as a source of creativity" (Fisher, 2012, p. 1039). Effectuation has promoted the means (what I am, what I know and whom I know) of the entrepreneur as a way of dealing with constraint posed by lack of resources. Moreover, as entrepreneurs strive to deal with the challenges of growth, effectual principles offer them a lifeline in a dynamic environment.

\section{GROWTH AND SMES' INTERNATIONALISATION}

Growth through internationalisation has been identified as another alternative through which SMEs overcome barriers to growth (Omer et al., 2015; Veronica et al., 2019). Internationalisation is seen as the expansion of target market from domestic to international markets by new ventures, and this is considered a vital performance driver that can increase firm feasibility (Zahra et al., 2000). SMEs are often faced with stiff challenges which limit their ability to grow domestically (Hessels \& Parker, 2013).

Scholars have examined the internationalisation process of SMEs, and this is not without challenges (Collins \& Reutzel, 2016). Contractor et al. (2007) acknowledge the impact of internationally expanding companies on the financial performance of firms as the process produces high costs and uncertainties. However, a quantitative study conducted by Pinho \& Prange (2016) in Portugal with 107 SME exporters, found that social network relationships of firms will positively affect their international performance. They further noted that obstacles in the internationalisation process could be minimised with the help of dynamic internationalisation capabilities through exploitative and explorative dynamic capabilities. This concept of network relationships has attracted scholarly attention because it is fundamental to internationalisation strategies (Kampouri et al., 2017). It has been noted that networks play a crucial role in SMEs' effort to reduce information asymmetry with the provision of access to information that is relevant to their international survival and growth (Zhou et al., 2007). In most cases, firms' 
decision to establish network relationship is a thoughtful strategic choice which is based on the resources they lack and the assets or resources that another actor in the network can offer (Hessels \& Parker, 2013). In particular, networks are necessary for small and medium-sized firms (SMEs) in foreign markets because of the challenges posed by lack of knowledge and resource constraints needed for internationalisation (Gilmore et al., 2006).

For optimal export performance, Brouthers et al. (2009) suggested that small firms from small countries should concentrate on a few overseas markets. Conversely, Casey \& Hamilton (2014: 254) examined a sample of 249 small New Zealand exporters reported that exporters should not just focus on one or a few foreign markets, however, they acknowledged that to be successful these small firms will spend more on R\&D and embrace "multi-market exporting through company-owned channels in distant markets". Interestingly, Galkina \& Chetty (2015) discovered that by utilising effectual logic entrepreneurs network with interested parties rather than making careful selection from numerous international partners and they do this by entering markets wherever an opportunity occurs establishing commitment with network relations that can increase their means. The network approach to SMEs' internationalisation is gaining recognition and helping international new ventures to overcome and navigate foreign markets with the associated challenges. Considering the size and the distance of Australia and New Zealand to the rest of the developed world, taking the growth path of internationalisation leaves SMEs with daunting obstacles that could be managed through effectual principles.

There are three significant modes of entry into international market, e.g. "foreign technology licensing, imports of intermediate production inputs and exporting"(Abubakar et al., 2019, p. 60). From empirical evidence, SMEs prefer an incremental approach such as exporting, presenting them the advantage of learning effects (Dominguez \& Mayrhofer, 2017). "In the process of exporting, SMEs gain exposure to various foreign markets and gradually build networks with local clients" (Lu \& Beamish, 2006, p.31). Exploiting a foreign market via exporting activities allow firms to launch out from their existing domestic base choosing to locate production plants and/or sales and marketing offices in other countries to boost their market development strategy (Abubakar et al., 2019).

Researchers have also linked exporting with innovation (Filippetti, Frenz, \& Ietto-Gillies, 2012). Meeting foreign customer expectations and the required standards in the host nations, firms innovate new products or processes. Examining exporting firms' data from a region in Chile between 2006 to 2011, Geldres-Weiss et al. (2016) found that strategic activities such as export market innovation and 
export product innovation enhance experiential knowledge which reduces risk and uncertainty associated with internationalisation. Concerning the decision-making process relating to foreign markets selection and entry, Chetty et al. (2015) noted that entrepreneurs use effectuation and causation logics, alternating the two in their decision-making. However, those with existing partners in foreign markets relied mostly on effectuation to select and enter international markets.

\section{ENTREPRENEURIAL MOTIVATION}

Entrepreneurial cognition is central in the entrepreneurial process (Baron, 2004; Mitchell et al., 2007). Understanding how entrepreneurs think can make understanding their actions more achievable. Entrepreneurship researchers have promoted the importance of entrepreneurial thinking because this plays a central role in entrepreneurial decision-making (Shepherd et al., 2015; Oyson \& Whittaker, 2015). These questions cut across vital entrepreneurial phenomena such as opportunity identification (Baldacchino et al., 2015) and growth: "Why are some entrepreneurs more motivated than others to grow their firms?" (Wright \& Stigliani, 2013, p.15). Gaglio (2004) proposes counterfactual thinking as one of the mechanisms through which entrepreneurs recognise and nurture innovative opportunities. In an experimental study Frederiks et al. (2019) found that the type of cognitive thinking employed by entrepreneurs impacts the quality of new venture ideas. They found that the use of future-oriented thinking such as prospective thinking, which could be enhanced by prior knowledge would lead to new venture ideas of higher quality compared to counterfactual thinking. However, Arora et al. (2013) suggest that the amplifying effects of experience could be hampered by the dispositional attributes of the entrepreneur resulting from their individual differences. The heterogeneity of the entrepreneurs' metacognitive thinking influences entrepreneurial growth decision making (Shepherd et al., 2015). Ginn \& Sexton (1990) found that the difference between owners of slower growth firms and rapid growth firms originates from their cognitive profile. Sadler-Smith (2004) also observed that cognitive styles positively impact sales growth, quality of products and services as well as the efficiency of operations. This shift of attention from traits of the entrepreneur to entrepreneurial cognition offers hope of understanding the entrepreneurial processes with deeper insights into how entrepreneurs think and the effects on entrepreneurial decision making (Armstrong et al., 2012).

For a more in-depth and better understanding of entrepreneurial cognition, scholars in the field of entrepreneurship have recommended that entrepreneurial 
motivation be revisited (Carsrud \& Brännback, 2011). Decision making in different stages of the entrepreneurial process has been heavily linked with motives of entrepreneurs (Jayawarna et al., 2013; Murnieks et al., 2019). Consequently, human motivation should not be overlooked in the entrepreneurial process because the dominant player is the entrepreneur. Entrepreneurs make decisions to commence the entrepreneurial process and are regularly called to make decisions all through the entrepreneurial process (Shepherd et al., 2015). Entrepreneurship scholars have investigated the motives for these entrepreneurial decisions. Initially, scholars believed that the primary motivation for entrepreneurial decision is economic gain (Carsrud \& Brännback, 2011) but social entrepreneurship is becoming prominent as some entrepreneurs are now devoted to societal benefit.

\section{Entrepreneurial Motivation for Venture Start-up}

There is a considerable amount of research on entrepreneurs' start-up motivations. These studies have identified factors that drive entrepreneurial motivation. For example, in a quantitative study of 401 nascent entrepreneurs in the United States, Edelman et al. (2010) found that desire for recognition and independence as well as financial success motivate entrepreneurs into new venture initiation. Studying a sample of 465 university students from cross-sectional data, Farhangmehr et al. (2016) established that competencies which are the bedrock of entrepreneurial self-efficacy, significantly predict entrepreneurial motivation. In the same vein, in their quantitative study of 237 samples from eastern Poland's Podlasie region, Tyszka et al. (2011) suggest that entrepreneurs high in self-efficacy are more motivated to exploit opportunities; however, this is only true with opportunitydriven entrepreneurs (not necessity-driven). To determine the effects of socioeconomic variables, Hessels et al. (2008) compared motives across and found that economies with GDP growth will have more entrepreneurs whose motivation for a start-up is to increase wealth while independence and necessity motive is prevalent with economies without GDP growth. They found that social security encourages necessity motive but discourages independence motive and shows no significant relationship with increase-wealth motivation.

\section{Entrepreneurial Motivation for Survival}

The world of business is very complex, and the battle for survival becomes real immediately after venture initiation. However, there is only a relatively small body of literature relating to entrepreneurs' motivation to survive. An exception is DeTienne 
et al. (2008), that examined factors that motivate entrepreneurs to persist when their firms are underperforming. They propose that their personal investment, previous venture success and perceived efficacy contribute significantly to their persistence, although entrepreneurs with other alternatives apart from underperforming firms are less likely to persist. In a qualitative study of 35 women-led service firms from Valencia in Spain, Rey-Martí et al. (2015), suggest that those with risk-taking motive are more likely to survive than those seeking better work-life balance.

Morris et al. (2012: 12) point out that by the "occurrence of salient events and the manner in which they are processed" profoundly influence risk-taking. Hence, entrepreneurs with positive feelings and peak experiences might embrace risk-taking actions while those with low arousal resulting from negative emotions might be riskaverse. Stenholm \& Renko (2016) argue that entrepreneurs with an intense positive feeling associated with an entrepreneurial role such as inventing and developing are likely to engage in "make-do" practices that could promote the survival of their firms. While striving to survive, new ventures try to increase their market presence motivating them to grow in areas that are vital to their survival.

\section{Entrepreneurial Motivation for Growth}

Although scholars study entrepreneurial growth extensively, understanding entrepreneurial motivations for growth continues to be an area that requires further investigation. Motivation for growth captures the attention of both practitioners and scholars but not as much as motivation for venture start-up (Achtenhagen et al., 2010; Murnieks et al., 2019). To date, several studies have investigated the impact of motivation on firm growth (Baum \& Locke, 2004; Delmar \& Wiklund, 2008; Wiklund et al., 2003) and a relationship has been established between growth motivation and firm growth. Questions such as "why are some entrepreneurs more motivated than others to grow their firms?" is suggested for scholarly probing (Wright \& Stigliani, 2013, p.15). Moen et al. (2016) analysed the quantitative data from 247 firms over 11 years. They concluded that motivation for growth was highly and frequently associated with international orientation, which greatly influences growth in revenue and exports.

A recent study by Gielnik et al. (2017) involving a sample of 201 small business managers with over 5 years of their firm performance data (which resulted in 836 observations) found a strong positive impact on venture performance over time for owner-managers who focused on entrepreneurial opportunities. In a multiple case study to characterise high-growth firms in New Zealand, (Hinton \& Hamilton, 2013) one of the four dimensions that describe their essential features is opportunity 
exploitation. This again stresses the importance of entrepreneurial opportunity in the growth of firms. Furthermore, Baum et al. (2001) suggest that vision, growth goals and self-efficacy impact entrepreneurs' motivation for growth. Baron et al. (2016) found that entrepreneurial self-efficacy positively impact venture growth and this relationship is mediated by goal difficulty. Tumasjan \& Braun (2012: 626) argue that "promising business ideas result from forward-looking visions". They propose that visions build promotion-focused individuals who are open-minded, embracing a variety of ideas to enhance venture performance. In their review of the literature on entrepreneurial growth, Wright \& Stigliani (2013) concluded that there is a need for more empirical studies on factors that influence entrepreneurs' motivation. A quantitative study of 122 high technology firms in the United States, Drnovsek et al. (2016) found that entrepreneurs who enjoy activities associated with the entrepreneurial role identity of a developer are motivated to grow their firms because of their commitment to growth goals. This view is supported by Mueller et al. (2017) who argue that passion for developing positively influences grit which positively relates to venture performance.

\section{$\overline{\text { CONCLUSION }}$}

Decades of international entrepreneurship research clearly points to the conclusion that entrepreneurial growth requires sufficient motivation on behalf of entrepreneurs as well as ample economic opportunities. Many factors were identified as having the potential to motivate entrepreneurs for growth. A continued systematic effort to understand the nuances of entrepreneurial motivation for growth could be quite fruitful. For example, perceived entrepreneurial opportunity could trigger growth motivation in entrepreneur, which might eventually lead to actual growth. However, it is almost taken as a given that entrepreneurs have a desire to achieve substantial growth. Entrepreneurs can have a wide range of motivations (some economic, many non-economic) and automatically assuming an inherent bias towards firm growth does not align with the reality of entrepreneurs around the globe. Firm growth frequently requires a willingness to make internal processes more standardized, an ongoing of scan the market for opportunities, the accumulation needed resources, and an increasing complexity in the operations of the firm. The research reviewed herein suggests that entrepreneurs throughout the world have varied motivations that influence the choices made on behalf of their firms. Thus, understanding the motivations of entrepreneurs might well be fertile research territory for the next several decades. 


\section{REFERENCES}

Abubakar, Y. A., Hand, C., Smallbone, D., \& Saridakis, G. (2019). What specific modes of internationalization influence SME innovation in Sub-Saharan least developed countries (LDCs)? Technovation, 7956-70.

Achtenhagen, L., Naldi, L., \& Melin, L. (2010). "Business growth" - Do practitioners and scholars really talk about the same thing? Entrepreneurship: Theory and Practice, 34(2), 289-316.

Agnihotri, A. (2014). Corporate reputation based theory of choice between organic, hybrid and inorganic growth strategies. Corporate Communications, 19(3), 247-259.

Akinboye, A., Morrish S., \& Collins J. (2019), "Entrepreneurial Motivation and Growth Intention: An Australasian Study", Global Research Symposium in Marketing and Entrepreneurship, Regents University, London, 27-39 June.

Armstrong, S. J., Cools, E., \& Sadler-Smith, E. (2012). Role of cognitive styles in business and management: Reviewing 40 years of research. International Journal of Management Reviews, 14(3), 238-262.

Arora, P., Haynie, J. M., \& Laurence, G. A. (2013). Counterfactual thinking and entrepreneurial self-efficacy: The moderating role of self-esteem and dispositional affect. Entrepreneurship Theory and Practice, 37(2), 359-385.

Arregle, J. L., Batjargal, B., Hitt, M. A., Webb, J. W., Miller, T., \& Tsui, A. S. (2015). Family ties in entrepreneurs' social networks and new venture growth. Entrepreneurship: Theory and Practice, 39(2), 313-344.

Baker, T., Grimes, M., Hamann, R., Hmieleski, K., Kim, P., Kim, S., Pollock, T. (2017). In the beginning: Identity processes and organizing in multi-founder nascent ventures. Academy of Management Journal, 60(6), 2381-2414.

Baldacchino, L., Ucbasaran, D., Cabantous, L., \& Lockett, A. (2015). Entrepreneurship research on intuition: A critical analysis and research agenda. International Journal of Management Reviews, 17(2), 212-231.

Barbera, F., \& Hasso, T. (2013). Do we need to use an accountant? The sales growth and survival benefits to family SMEs. Family Business Review, 26(3), 271-292.

Baron, R. A., Mueller, B. A., \& Wolfe, M. T. (2016). Self-efficacy and entrepreneurs' adoption of unattainable goals: The restraining effects of self-control. Journal of Business Venturing, 31(1), 55-71.

Bartlett, W., \& Bukvič, V. (2001). Barriers to SME growth in Slovenia. Economic Policy in Transitional Economies, 11(2), 177-195. 
Bartz, W., \& Winkler, A. (2016). Flexible or fragile? The growth performance of small and young businesses during the global financial crisis - Evidence from Germany. Journal of Business Venturing, 31(2), 196-215.

Baù, M., Chirico, F., Pittino, D., Backman, M., \& Klaesson, J. (2019). Roots to grow: Family firms and local embeddedness in rural and urban contexts. Entrepreneurship: Theory and Practice, 43(2 Special Issue), 360-385.

Baum, J. R., \& Locke, E. A. (2004). The relationship of entrepreneurial traits, skill, and motivation to subsequent venture growth. Journal of Applied Psychology, 89(4), 587-598.

Baum, J. R., Locke, E. A., \& Smith, K. E. N. G. (2001). A multidimensional model of venture growth. Academy of Management Journal, 44(2), 292-303.

Beck, T., \& Demirguc-Kunt, A. (2006). Small and medium-size enterprises: Access to finance as a growth constraint. Journal of Banking and Finance, 30(11), 2931-2943.

Biraglia, A., \& Kadile, V. (2017). The role of entrepreneurial passion and creativity in developing entrepreneurial intentions: Insights from American homebrewers. Journal of Small Business Management, 55(1), 170-188.

Bradley, S. W., Wiklund, J., \& Shepherd, D. A. (2011). Swinging a double-edged sword: The effect of slack on entrepreneurial management and growth. Journal of Business Venturing, 26(5), 537-554.

Brouthers, L. E., Nakos, G., Hadjimarcou, J., \& Brouthers, K. D. (2009). Key factors for successful export performance for small firms. Journal of International Marketing, 17(3), 21-38.

Cardon, M. S., Glauser, M., \& Murnieks, C. Y. (2017). Passion for what? Expanding the domains of entrepreneurial passion. Journal of Business Venturing Insights, 8, 24-32.

Cardon, M. S., Gregoire, D. A., Stevens, C. E., \& Patel, P. C. (2013). Measuring entrepreneurial passion: Conceptual foundations and scale validation. Journal of Business Venturing, 28(3), 373-396.

Cardon, M. S., \& Kirk, C. P. (2015). Entrepreneurial passion as mediator of the self-efficacy to persistence relationship. Entrepreneurship: Theory and Practice, 39(5), 1027-1050.

Casey, S. R., \& Hamilton, R. T. (2014). Export performance of small firms from small countries: The case of New Zealand. Journal of International Entrepreneurship, 12(3), 254-269.

Carsrud, A., \& Brännback, M. (2011). Entrepreneurial motivations: What do we still need to know? Journal of Small Business Management, 49(1), 9-26. 
Chandler, G. N., McKelvie, A., \& Davidsson, P. (2009). Asset specificity and behavioral uncertainty as moderators of the sales growth - Employment growth relationship in emerging ventures. Journal of Business Venturing, 24(4), 373-387.

Chen, X.-P., Yao, X., \& Kotha, S. (2009). Entrepreneur passion and preparedness in business plan presentations: a persuasion analysis of venture capitalists' funding decisions. Academy of Management Journal, 52(1), 199-214.

Chen, X., Zou, H., \& Wang, D. T. (2009). How do new ventures grow? Firm capabilities, growth strategies and performance. International Journal of Research in Marketing, 26(4), 294-303.

Chetty, S., Ojala, A., \& Leppäaho, T. (2015). Effectuation and foreign market entry of entrepreneurial firms. European Journal of Marketing, 49(9-10), 1436-1459.

Collins, J. D., \& Reutzel, C. R. (2017). The role of top managers in determining investment in innovation: The case of small \& medium enterprises in India. International Small Business Journal, 35, 1-21.

Collins, J. D., McMullen, J. S., \& Reutzel, C. R. (2016). Distributive justice, corruption, and entrepreneurial behavior. Small Business Economics, 47(4), 981-1006.

Collins, J. D., \& Reutzel, C. R. (2016). Entrepreneurial strategies for emerging markets. Journal of Business Strategies. 33(1).

Dagnino, G. B., King, D. R., \& Tienari, J. (2017). Strategic management of dynamic growth. Long Range Planning, 50(4), 427-430.

Daily, C. M., \& Thompson, S. S. (1994). Ownership structure, strategic posture, and firm growth: An empirical examination. Family Business Review, 7(3), 237-249.

Dalborg, C., \& Wincent, J. (2015). The idea is not enough: The role of self-efficacy in mediating the relationship between pull entrepreneurship and founder passion - a research note. International Small Business Journal, 33(8), 974-984.

Davidsson, P. (1991). Continued entrepreneurship: Ability, need, and opportunity as determinants of small firm growth. Journal of Business Venturing, 6(6), 405-429.

Davidsson, P., Achtenhagen, L., \& Naldi, L. (2010). Small Firm Growth. Foundations and Trends in Entrepreneurship, 69-166.

Davidsson, P., Steffens, P., \& Fitzsimmons, J. (2009). Growing profitable or growing from profits: Putting the horse in front of the cart? Journal of Business Venturing, 24(4), 388-406.

Davidsson, P., \& Wiklund, J. (2006). Conceptual and empirical challenges in the study of firm growth. Entrepreneurship and the Growth of Firms, 1(1), 39-61. 
Delmar, F., Davidsson, P., \& Gartner, W. B. (2003). Arriving at the high-growth firm. Journal of Business Venturing, 18(2), 189-216.

Delmar, F., \& Wiklund, J. (2008). The effect of small business managers' growth motivation on firm growth: A longitudinal study. Entrepreneurship: Theory and Practice, 32(3), 437-457.

DeTienne, D. R., Shepherd, D. A., \& De Castro, J. O. (2008). The fallacy of “only the strong survive": The effects of extrinsic motivation on the persistence decisions for under-performing firms. Journal of Business Venturing, 23(5), 528-546.

Dobbs, M., \& Hamilton, R. T. (2007). Small business growth: Recent evidence and new directions. In International Journal of Entrepreneurial Behaviour and Research, (13(5), 296-322.

Dominguez, N., \& Mayrhofer, U. (2017). Internationalization stages of traditional SMEs: Increasing, decreasing and re-increasing commitment to foreign markets. International Business Review, 26(6), 1051-1063.

Douglas, E. J. (2013). Reconstructing entrepreneurial intentions to identify predisposition for growth. Journal of Business Venturing, 28(5), 633-651.

Douglas, E. J., \& Shepherd, D. (2002). Exploring investor readiness: Assessments by entrepreneurs and investors in Australia. Venture Capital, 4(3), 219-236.

Drnovsek, M., Cardon, M. S., \& Patel, P. C. (2016). Direct and indirect effects of passion on growing technology ventures. Strategic Entrepreneurship Journal, 10(2), 194-213.

Dutta, D. K., \& Thornhill, S. (2008). The evolution of growth intentions: Toward a cognition-based model. Journal of Business Venturing, 23(3), 307-332.

Dutta, D. K., \& Thornhill, S. (2014). Venture cognitive logics, entrepreneurial cognitive style, and growth intentions: A conceptual model and an exploratory field study. Entrepreneurship Research Journal, 4(2), 147-166.

Edelman, L. F., Brush, C. G., Manolova, T. S., \& Greene, P. G. (2010). Start-up motivations and growth intentions of minority nascent entrepreneurs. Journal of Small Business Management, 48(2), 174-196.

Farhangmehr, M., Gonçalves, P., \& Sarmento, M. (2016). Predicting entrepreneurial motivation among university students. Education + Training, 58(7), 861-881.

Filippetti, A., Frenz, M., \& Ietto-Gillies, G. (2012). The role of internationalization as a determinant of innovation performance: an analysis of 42 countries. CIMR Research Working Paper Series No. 1051 (6): 1006-1022

Fisher, G. (2012). Effectuation, causation, and bricolage: A behavioral comparison of emerging theories in entrepreneurship research. Entrepreneurship: Theory and Practice, 36(5), 1019-1051. 
Frederiks, A. J., Englis, B. G., Ehrenhard, M. L., \& Groen, A. J. (2019). Entrepreneurial cognition and the quality of new venture ideas: An experimental approach to comparing future-oriented cognitive processes. Journal of Business Venturing, $34(2), 327-347$.

Gagliardi, F. (2009). Financial development and the growth of cooperative firms. Small Business Economics, 32(4), 439-464.

Gaglio, C. M. (2004). The role of mental simulations and counterfactual thinking in the opportunity identification process. Entrepreneurship: Theory and Practice, 28(6), 533-552.

Galkina, T., \& Chetty, S. (2015). Effectuation and networking of internationalizing SMEs. Management International Review, 55(5), 647-676.

Geldres-Weiss, V. V., Uribe-Bórquez, C. T., Coudounaris, D. N., \& Monreal-Pérez, J. (2016). Innovation and experiential knowledge in firm exports: Applying the initial U-model. Journal of Business Research, 69(11), 5076-5081.

Gibb, A. A. (2000). SME policy, academic research and the growth of ignorance, mythical concepts, myths, assumptions, ritual and confusions. International Small Business Journal, 18(3), 13-35.

Gibb, A., \& Davies, L. (1990). In pursuit of frameworks for the development of growth models of the small business. International Small Business Journal, 9(1), $15-31$.

Gilbert, B. A., McDougall, P. P., \& Audretsch, D. B. (2006). New venture growth: A review and extension. Journal of Management, 32(6), 926-950.

Gill, A., \& Biger, N. (2012). Barriers to small business growth in Canada. Journal of Small Business and Enterprise Development, 19(4), 656-668.

Gill, A., \& Mand, H. S. (2013). Barriers to the growth of small business firms in India. International Journal of Business and Globalisation, 10(1), 1-13.

Gilmore, A., Carson, D., \& Rocks, S. (2006). Networking in SMEs: Evaluating its contribution to marketing activity. International Business Review, 15(3), 278293.

Haeussler, C., Hennicke, M., \& Mueller, E. (2019). Founder-inventors and their investors: Spurring firm survival and growth. Strategic Entrepreneurship Journal, 13(3), 288-325.

Hansen, B., \& Hamilton, R. T. (2011). Factors distinguishing small firm growers and non-growers. International Small Business Journal, 29(3), 278-294.

Hashi, I. (2001). Financial and institutional barriers to SME growth in Albania: Results of an enterprise survey. Economic Policy in Transitional Economies, 11(3), 221-238. 
Havnes, P. A., \& Senneseth, K. (2001). A Panel Study of Firm Growth among SMEs in Networks. Small Business Economics, 16(4), 293-302.

Heshmati, A. (2001). On the growth of micro and small firms: Evidence from Sweden. Small Business Economics, 17(3), 213-228.

Hessels, J., \& Parker, S. C. (2013). Constraints, internationalization and growth: A cross-country analysis of European SMEs. Journal of World Business, 48(1), $137-148$.

Hessels, J., Van Gelderen, M., \& Thurik, R. (2008). Entrepreneurial aspirations, motivations, and their drivers. Small Business Economics, 31(3), 323-339.

Hitt, M. A., Ireland, R. D., \& Lee, H. (2000). Technological learning, knowledge management, firm growth and performance: an introductory essay. Journal of Engineering and Technology Management, 17(3-4), 231-246.

Jayawarna, D., Rouse, J., \& Kitching, J. (2013). Entrepreneur motivations and life course. International Small Business Journal, 31(1), 34-56.

Kampouri, K., Plakoyiannaki, E., \& Leppäaho, T. (2017). Family business internationalisation and networks: emerging pathways. Journal of Business and Industrial Marketing, 32(3), 357-370.

Knockaert, M., Foo, M. Der, Erikson, T., \& Cools, E. (2015). Growth intentions among research scientists: A cognitive style perspective. Technovation, 38, 64-74.

Koryak, O., Mole, K. F., Lockett, A., Hayton, J. C., Ucbasaran, D., \& Hodgkinson, G. P. (2015). Entrepreneurial leadership, capabilities and firm growth. International Small Business Journal: Researching Entrepreneurship, 33(1), 89-105.

Krasniqi, B. A. (2007). Barriers to entrepreneurship and SME growth in transition: The Case of Kosova. Journal of Developmental Entrepreneurship, 12(01), 71-94.

Lee, N. (2014). What holds back high-growth firms? Evidence from UK SMEs. Small Business Economics, 43(1), 183-195.

Leitch, C., Hill, F., \& Neergaard, H. (2013). Entrepreneurial and business growth and the quest for a "comprehensive theory": tilting at windmills? Entrepreneurship Theory and Practice, 34(2), 249-260.

Lockett, A., Wiklund, J., Davidsson, P., \& Girma, S. (2011). Organic and Acquisitive Growth: Re-examining, Testing and Extending Penrose's Growth Theory. Journal of Management Studies, 48(1), 48-74.

Lu, J. W., \& Beamish, P. W. (2006). SME internationalization and performance: Growth vs. profitability. Journal of International Entrepreneurship, 4(1), 27-48. Markman, G. D., \& Gartner, W. B. (2002). Is extraordinary growth profitable? A study of Inc. 500 high-growth companies. Entrepreneurship Theory and Practice, 27(1), 65-75. 
Mason, C., \& Brown, R. (2013). Creating good public policy to support high-growth firms. Small Business Economics, 40(2), 211-225.

Mazzarol, T., \& Clark, D. (2016). The evolution of small business policy in Australia and New Zealand. Small Enterprise Research, 23(3), 239-261.

McKelvie, A., \& Wiklund, J. (2010). Advancing firm growth research: A focus on of growth rate. Entrepreneurship Theory and Practice, (315), 261-289.

Mitchell, R. K., Busenitz, L. W., Morse, E. a, \& Smith, J. B. (2007). The central question in entrepreneurial cognition research. Entrepreneurship: Theory and Practice, (806), 1-27.

Moen, O., Heggeseth, A. G., \& Lome, O. (2016). The positive effect of motivation and international orientation on SME growth. Journal of Small Business Management, 54(2), 659-678.

Moreno, A. M., \& Casillas, J. C. (2008). Entrepreneurial orientation and growth of SMEs: A causal model. Entrepreneurship: Theory and Practice, 32(3), 507-528.

Morris, M. H., Kuratko, D. F., Schindehutte, M., \& Spivack, A. J. (2012). Framing the entrepreneurial experience. Entrepreneurship Theory and Practice, 36(1), $11-40$.

Morris, M. H., Neumeyer, X., Jang, Y., \& Kuratko, D. F. (2016). Distinguishing types of entrepreneurial ventures: an identity-based perspective. Journal of Small Business Management, pp. 1-22.

Mueller, B. A., Wolfe, M. T., \& Syed, I. (2017). Passion and grit: An exploration of the pathways leading to venture success. Journal of Business Venturing, 32(3), 260-279.

Murnieks, C. Y., Klotz, A. C., \& Shepherd, D. A. (2019). Entrepreneurial motivation: A review of the literature and an agenda for future research. Journal of Organizational Behavior, 1-29.

Naldi, L., \& Davidsson, P. (2014). Entrepreneurial growth: The role of international knowledge acquisition as moderated by firm age. Journal of Business Venturing, 29(5), 687-703.

Nason, R. S., \& Wiklund, J. (2018). An assessment of resource-based theorizing on firm growth and suggestions for the future. Journal of Management, 44(1), $32-60$.

Nuscheler, D., Engelen, A., \& Zahra, S. A. (2019). The role of top management teams in transforming technology-based new ventures' product introductions into growth. Journal of Business Venturing, 34(1), 122-140. 
O'Gorman, C. (2001). The sustainability of growth in small- and medium-sized enterprises. International Journal of Entrepreneurial Behaviour \& Research, 7(2): 60-75.

Omer, N., Burg, E. Van, Peters, R. M., \& Visser, K. (2015). Internationalization as a "work-around" strategy: how going abroad can help SMEs overcome local constraints. Journal of Developmental Entrepreneurship, 20(02), 1550011.

Pinho, J. C., \& Prange, C. (2016). The effect of social networks and dynamic internationalization capabilities on international performance. Journal of World Business, 51(3), 391-403.

Puente, R., Cervilla, M. A., González, C. G., \& Auletta, N. (2017). Determinants of the growth aspiration: a quantitative study of Venezuelan entrepreneurs. Small Business Economics, 48(3), 699-726.

Rasmussen, C. C., Ladegard, G., \& Korhonen-Sande, S. (2016). Growth intentions and board composition in high-growth firms. Journal of Small Business Management, 00(00), 1-17.

Rey-Martí, A., Tur Porcar, A., \& Mas-Tur, A. (2015). Linking female entrepreneurs' motivation to business survival. Journal of Business Research, 68(4), 810-814. Robson, P. J. A., \& Obeng, B. A. (2008). The barriers to growth in Ghana. Small Business Economics, 30(4), 385-403.

Romero-Jordán, D., Sanz-Labrador, I., \& Sanz-Sanz, J. F. (2019). Is the corporation tax a barrier to productivity growth? Small Business Economics, 1-16.

Sadler-Smith, E. (2004). Cognitive style and the management of small and mediumsized enterprises. Organization Studies, 25(2), 155-181.

Shepherd, D. A., \& Wiklund, J. (2009). Are we comparing apples with apples or apples with oranges? Appropriateness of knowledge accumulation across growth studies. Entrepreneurship Theory and Practice, 33(1), 105-123.

Shepherd, D. A., Williams, T. A., \& Patzelt, H. (2015). Thinking about entrepreneurial decision making: Review and research agenda. Journal of Management, 41(1), $11-46$.

Spence, M., Orser, B., \& Riding, A. (2011). A comparative study of international and domestic new ventures. Management International Review, 51(1), 3-21.

Steffens, P., \& Omarova, A. (2019). Global Entrepreneurship Monitor (GEM) 201718 Australian National Report.

Stenholm, P. (2011). Innovative behavior as a moderator of growth intentions. Journal of Small Business Management, 49(2), 233-251. 
Tumasjan, A., \& Braun, R. (2012). In the eye of the beholder: How regulatory focus and self-efficacy interact in influencing opportunity recognition. Journal of Business Venturing, 27(6), 622-636.

Vermeulen, P. A M., \& Curşeu, P. L. (2010). Entrepreneurial strategic decisionmaking: A cognitive perspective. In International Journal of Entrepreneurial Behaviour Research (15).

Veronica, S., Shlomo, T., Antonio, M. P., \& Victor, C. (2019). International social SMEs in emerging countries: Do governments support their international growth? Journal of World Business.

Wang, Y. (2016). What are the biggest obstacles to growth of SMEs in developing countries? - An empirical evidence from an enterprise survey. Borsa Istanbul Review, 16(3), 167-176.

Weinzimmer, L. G., Nystrom, P. C., \& Freeman, S. J. (1998). Measuring organizational growth: Issues, consequences and guidelines. Journal of Management, 24(2), 235-262.

Wennberg, K., Delmar, F., \& Mckelvie, A. (2016). Variable risk preferences in new firm growth and survival. Journal of Business Venturing, 31(4), 408-427.

Wiklund, J., Davidsson, P., \& Delmar, F. (2003). What do they think and feel about growth? An expectancy-value approach to small business managers' attitudes toward growth. Entrepreneurship: Theory and Practice, 27(3), 247-270.

Wiklund, J., Patzelt, H., \& Shepherd, D. A. (2009). Building an integrative model of small business growth. Small Business Economics, 32(4), 351-374.

Wiklund, J., \& Shepherd, D. (2003). Aspiring for and achieving growth: The moderating role of resources and opportunities. Journal of Management Studies, 40(8), 1919-1941.

Worku, Z. (2016). Barriers to the growth of small, micro and medium-sized business enterprises in the Vaal Triangle region of South Africa. African Journal of Science, Technology, Innovation and Development, 8(2), 134-141.

Wright, M., \& Stigliani, I. (2013). Entrepreneurship and growth. International Small Business Journal, 31(1), 3-22.

Yang, C. H., \& Tsou, M. W. (2019). Globalization and firm growth: Does ownership matter? Small Business Economics, (2013).

Zahra, S. A. (1996). Technology strategy and new venture performance: A study of corporate-sponsored and independent biotechnology ventures. Journal of Business Venturing, 11(4), 289-321. 
Zahra, S. A., Ireland, R. D., \& Hitt, M. A. (2000). International expansion by new venture firms: International diversity, mode of market entry, technological learning, and performance. Academy of Management Journal, 43(5), 925-950. Zahra, S. A., Sapienza, H. J., \& Davidsson, P. (2006). Entrepreneurship and dynamic capabilities: A review, model and research agenda. Journal of Management Studies, 43(4), 917-955.

Zhou, L., Wu, W. P., \& Luo, X. (2007). Internationalization and the performance of born- global SMEs: The mediating role of social networks. Journal of International Business Studies, 38(4), 673-690.

\section{BIOGRAPHICAL SKETCH OF AUTHORS}

Abayomi K. Akinboye earned his Ph.D. in the Department of Management, Marketing and Entrepreneurship at the University of Canterbury. His doctoral thesis investigates Entrepreneurial Growth Intention and Effectual Logic.

Jamie D. Collins is Professor and University Chair of Strategy, Innovation \& Entrepreneurship at University of Canterbury where he teaches post-graduate courses. He also holds Professorial Fellow status at Clemson University. He earned his Ph.D. from Texas A\&M University. Jamie's research examines the influence that perceptions of entrepreneurs and strategic leaders exert on their deliberate choices to invest organizational resources in the pursuit of innovation opportunities, in various institutional contexts.

Sussie C. Morrish is Associate Professor of Marketing at the University of Canterbury where she teaches strategic marketing and social entrepreneurship. She gained her PhD from the University of Canterbury while simultaneously teaching at the University of Auckland Business School. Her main research interests revolve around the marketing and entrepreneurship interface including various strategic approaches to post-disaster business recovery, internationalisation, sustainability and entrepreneurial ecosystems. 